\title{
Polymorphisms of TAS1R3 and GNAT3 Genes Are Associated with Patients with Taste Disorder
}

\author{
Jae-Woong Bae ${ }^{1 \dagger}$, Un-Kyung Kim" ${ }^{1 \dagger}$, Tae-Jun Kwon ${ }^{1}$, Su-Jin Choi ${ }^{1}$ and Mi-Kyung Ye ${ }^{2} \star$ \\ ${ }^{1}$ Department of Biology, College of Natural Sciences, Kyungpook National University, Daegu 702-701, Korea \\ ${ }^{2}$ Department of Otolaryngology-Head and Neck Surgery, College of Medicine, Catholic University of Daegu, Daegu 705-718, Korea
}

Received December 10, 2010/Accepted March 14, 2011

\begin{abstract}
Taste sensation plays a crucial role in selecting and ingesting foods with different qualities which convey information about their nutrient content and/or safety. Sweetness is one of the five modalities in humans and serves as an energy resource for metabolism. There are reports on allelic polymorphisms which influence perception of sweetness in mice and humans. Since the influence of genetic factors on taste disorder has not been studied, we investigated the association of genetic polymorphisms in TAS1R3 and guanine nucleotide binding protein, alpha transducing 3 (GNAT3) genes and taste disorder. A total of 150 individuals composed of 50 patients with taste disorder and 100 healthy controls were recruited for the study and PCR-mediated directing sequencing method was used to genotype for two different single nucleotide polymorphisms (SNPs) - rs307355 (T $>$ C) and rs35744813 $(\mathrm{T}>\mathrm{C})$ in the TAS1R3 gene, and rs7792845 $(\mathrm{T}>\mathrm{C})$ and $\mathrm{rs} 1524600(\mathrm{C}>\mathrm{T})$ in the the GNAT3 gene. The allele and genotype frequencies of rs307355 and rs35744813 in the TAS1R3 gene showed a significant association between patients with taste disorder ( $p=0.022$ and $p=0.013$ in both of SNPS, respectively). In addition, the frequency of T-T haplotype in the TAS1R3 gene was higher in taste disorder cases than in the controls (OR, 1.93: 95\%. CI, 1.09-3.39, $p=0.022$ ). In the GNAT3, the genotype frequency of rs7792845 in the patients was also different from the controls $(p=0.048)$, but allele frequency was not significantly associated in either group. Our result provides the frequencies of SNPs and haplotypes of the TAS1R3 and GNAT3 genes for the fundamental information of nutrigenetics in perception of the taste of sweetness in the Korean population. Also, the study suggests that the allelic polymorphisms of TAS1R3 and GNAT3 genes may be useful as a molecular marker for evaluating patients with taste disorder. Further studies with large samples are required to clarify our observation.
\end{abstract}

Key words : Sweet taste, taste disorder, gene, single nucleotide polymorphism, association

\section{서 론}

미각은 오감 중의 하나로, 생명을 유지하고 음식을 선택하 는데 가장 중요한 감각이다. 인간이 느낄 수 있는 다섯 가지 맛(단맛, 쓴맛, 신맛, 짠맛, 그리고 감칠맛) 중 단맛은 포도당 등 각종 당분자가 $\mathrm{G}$-단백 연결 수용체군 $(\mathrm{G}$ protein-coupled receptors)에 속하는 단맛 수용체에 결합할 때 시작되며, 당분 자 - 단맛 수용체간의 결합에 의해 수용체의 구조가 바뀌면서 세포 안에서의 일련의 신호전달 과정이 일어나게 되고 맛봉오 리의 기저부에 접합하고 있는 구심성 미각 신경 섬유를 따라 뇌로 신호가 전달되어 단맛을 인지하게 된다[1,4,8,10,12].

2001년 Nelson 등[8]이 TAS1R2 (taste receptor, type 1, member2)와 TAS1R3 (taste receptor, type 1, member3)로 이 루어진 이형이합체(heterodimer)가 당류, 인공 감미료 및 monellin과 brazzein 등의 sweet-tasting proteins에 결합하는

*Corresponding author

Tel : 82-53-650-4525, Fax : +82-53-650-4533

E-mail:miky@cu.ac.kr

These authors contributed equally in this study.
수용체라는 사실을 규명한 이후로, 단맛수용체에 대한 분자적 메커니즘에 대한 연구가 활발히 진행 중에 있으나[5,11], 단맛 을 인지하는 개인간의 차이에 대한 분자생물학적 연구는 부족 한 실정이다. 최근 Fushan 등 [2-3]이 TAS1R3 유전자 프로모 터 영역의 -1572 및 -1266 에 위치한 두 종류의 단일염기서열다 형성(Single nucleotide polymorphism, SNP)인 rs307355 $(\mathrm{C}<\mathrm{T})$ 및 $\mathrm{rs} 35744813(\mathrm{C}<\mathrm{T})$ 와 taste-specific $\mathrm{G} \alpha$ protein subunit인 gustducin을 암호화하는 guanine nucleotide binding protein, alpha transducing 3 (GNAT3) 유전자의 rs7792845 $(\mathrm{T}<\mathrm{C})$ 와 $\mathrm{rs} 1524600(\mathrm{~T}<\mathrm{C})$ 다형성이 단맛을 느끼는 개체간 민 감도 차이와 관련성이 있다는 사실을 규명함으로써, 맛을 인 지하는 능력과 유전적 요인간의 관계에 대한 관심이 높아지고 있다.

현대사회는 급속한 경제적 성장으로 인간의 생활 수준이 높아지게 됨에 따라 삶의 질에 대한 관심이 증가하고 있으며 바쁜 사회생활로 인해 각종 인스턴트 식품 및 인공 첨가물의 섭취가 늘어나고 있다. 또한, 의학의 발달로 인간의 평균수명 이 연장됨에 따라 노령화 사회로 접어들고 있다. 이러한 경제 적 ·사회적 변화 속에 미각이 상실되거나 감소 또는 증가되는 
미각 장애 환자가 점점 증가하는 추세이다. 현재까지 알려진 바에 따르면, 미각 장애는 국소적 및 전신적 요인들이 복합적 으로 관여하여 발생하는 것으로 여겨지고 있으나, 아직까지 유발 인자들에 대해서는 명확하게 밝혀진 바가 없다. 우리나 라의 경우, $\operatorname{Lim}$ 등[7]이 미각 장애 환자의 임상적 고찰에 대한 보고한 바는 있으나, 아직까지 분자적 수준의 연구는 수행된 바가 없다. 이에 본 연구에서는 미각장애환자와 정상인간에 단맛 민감도에 영향을 미치는 유전적 다형성에 대해 연관성이 있는지를 조사해 봄으로써 미각장애에 미치는 유전적 요인을 알아보고자 하였다.

\section{재료 및 방법}

\section{대상}

본 연구는 자원자 모집 광고를 통해 모집된 19세 이상의 정상 성인 남녀 100 명과 미각 장애로 대구가톨릭대학교병원 이비인후과 후각-미각클리닉으로 내원한 50명의 환자를 대상 으로 하였다. 대상자에게 시행된 모든 검사들은 대구가톨릭대 학교병원 임상시험 심사위원회(Institutional Reviewer Board, IRB)의 승인 하에 모든 대상에서 미각 검사 및 미각 유전자 분석 연구에 대한 동의서를 받았으며, 미각과 연관된 개인의 습성과 복용중인 약물, 코, 귀, 구강, 위장관, 침분비 등 미각에 영향을 미치는 질환에 대한 설문지를 작성하게 하였다. 검사 1 시간 전에는 흡연을 금하였으며, 물을 제외한 음료 및 식사를 못하도록 하였다. 모든 대상에서 전기미각검사와 유전자 분석 을 시행하였다.

\section{전기미각검사}

전기미각계(electrogustometer, TR-06, Rion, Japan)를 사용 하여 혀끝에서 $2 \mathrm{~cm}$ 떨어진 변연부위, 입새유두(foliate papilla) 근처, 연구개 부위의 각각 좌우 총 6 군데에서 미각 역치를 측정하였다. 피험자를 편안한 자세로 의자에 앉힌 후 불관전 극을 피검자의 목부분에 살며시 끼웠다. 전기미각계의 응답용 버튼 스위치를 잡게 하고 단극도자를 측정부위에 위치시킨 후 기기의 다이얼을 한 단계씩 올리며 피검자로 하여금 처음 미각의 변화를 느끼는 순간에 응답용 버튼 스위치를 누르게 하였다. 이와 같은 과정을 5 분 간격으로 3 회 실시하여 평균치 를 구하여 그 부위에 대한 전기미각역치로 정하였다.

\section{유전자 다형성 분석}

실험 대상들의 말초혈액에서 $10 \mathrm{ml}$ 의 정맥혈을 채혈하여 FlexiGene DNA kit (Qiagen, Inc., USA)를 이용하여 genomic $\mathrm{DNA}$ 를 추출하였다. 각 $\mathrm{DNA}$ 의 양은 분광계(spectrometer)로 측정하여 $25 \mathrm{ng} / \mu 1$ 로 균일하게 희석시켰다.

TAS1R3 유전자 프로모터 영역의 $\mathrm{rs} 307355(\mathrm{C}<\mathrm{T})$ 및 $\mathrm{rs} 35744813(\mathrm{C}<\mathrm{T})$ 와 GNAT3 유전자의 $\mathrm{rs} 7792845(\mathrm{~T}<\mathrm{C})$ 와 rs1524600 $(\mathrm{T}<\mathrm{C})$ 부위를 특이적으로 증폭할 수 있는 프라이머 를 Primer3 프로그램을 이용하여 제작하였으며, 각 프라이머 의 염기서열은 아래와 같다.

TAS1R3-F : 5'-acgtatgtgctgcgtgttg-3'

TAS1R3-R : 5'-catgctgagcacacgtgaat-3'

GNAT3(rs7792845)-F : 5'-acacccaaag aaggcaaatg-3'

GNAT3(rs7792845)-R : 5'-cacgctactgagctttggtg-3'

GNAT3(rs1524600)-F : 5'-ggttacatccgctttgcagt-3'

GNAT3(rs1524600)-R : 5'-ttcatcagtgtcgtctgaatgac-3'

각 $\mathrm{PCR}$ (polymerase chain reaction)은 $25 \mathrm{ng}$ template $\mathrm{ge}^{-}$ nomic DNA, $2.5 \mu 1$ 10× PCR reaction buffer, $1.5-2 \mathrm{mM}$ $\mathrm{MgCl}_{2}, 0.2 \mu \mathrm{M}$ dNTP, $15 \mathrm{pmol}$ 양쪽 primers, $0.75 \mathrm{U}$ Taq DNA polymerase (Solgent, Korea), 그리고 $\mathrm{dH}_{2} \mathrm{O}$ 를 넣어 최종 부피를 $25 \mu 1$ 로 맞춘 후 잘 섞은 다음 반응을 시행하였다. 각 $\mathrm{PCR}$ cycle은 $95^{\circ} \mathrm{C}$ 에서 2 분간 denaturation시킨 후, $94^{\circ} \mathrm{C}$ 에서 30 초, 각 primer들의 $\mathrm{Tm}$ 온도에 따라 30 초, $72^{\circ} \mathrm{C}$ 에서 1 분간의 조건으로 35 cycles, 그리고 $72^{\circ} \mathrm{C}$ 에서 10 분으로 최종 합성하였 다. $5 \mu \mathrm{l}$ 의 PCR산물은 $1.5 \%$ agarose gel에 전기영동을 수행하 여 PCR 증폭여부 및 크기를 확인하였다. 증폭된 PCR products의 경우, $3 \mathrm{U}$ exonuclease I (USB, Co., USA)와 $0.3 \mathrm{U}$ alkaline phosphatase (USB, Co., USA)를 넣어 섞은 다음, $37^{\circ} \mathrm{C}$ 에 서 1시간 incubation시킨 후, $80^{\circ} \mathrm{C}$ 에서 15 분간 처리, direct sequencing 의 주형으로 이용하였다. PCR product에 대한 염기 서열 결정은 $\mathrm{ABI} 3130 \mathrm{XL}$ 자동염기서열 분석기를 이용하며, DNA Sequencing Analysis software (ver.5.0)로 분석하였다.

유전자 변이 분석은 LASERGENE-SeqMan 및 PHRED/ PHRAP/CONSED software suite를 이용하여 알아내었다. 각 유전자에 대한 일배체형은 동형접합체(homozygote)나 PHASE 2.0.2 프로그램을 이용하여 추론하였다.

\section{통계분석}

각 $\mathrm{SNP}$ 및 일배체형과 미각장애 간의 연관성 분석을 위한 통계 처리는 SPSS (statistical package for the social science) 18.0 for Windows (SPSS Inc., Chicago, IL, USA)를 이용하여 분석하였다. 대립형질의 빈도는 측정된 유전자형의 수를 근거 로 계산하였고, 유전자형의 분포가 Hardy-Weinberg 평형 (Hardy-Weinberg equilibrium HWE)을 따르는지에 대한 여 부 및 환자군과 대조군간의 유전자형의 빈도와 질환과의 연관 성여부에 대한 차이는 카이제곱 방법(chi-square test)을 사용 하였으며, 대립유전자 및 일배체형의 빈도에 대한 두 군의 비 교를 위해 위험도와 신뢰구간을 측정하였다. 분석된 모든 결 과는 $95 \%$ 수준 $(p<0.05)$ 에서 통계적 유의성을 검정하였다.

\section{결과 및 고찰}

TAS1R3 유전자의 rs307355 및 rs35744813에 대한 미각 장 
애 환자군과 정상 대조군의 대립인자형 및 유전자형 빈도 분 포는 Table 1과 같다. 전체 환자군과 대조군의 두 종류의 유전 자 다형성들에 대한 유전자형의 분포는 모두 $\mathrm{HWE}$ 을 따랐다. rs 307355 의 유전자형은 미각 장애 환자군에서는 $\mathrm{C} / \mathrm{C} 56 \%$, C/T 30\%, T/T 14\% 였으며 대조군은 C/C 67\%, C/T 31\%, $\mathrm{T} / \mathrm{T} 2 \%$ 로 통계적으로 유의한 차이가 있었다 $(p<0.013)$. T allele은 환자군에서 $29 \%$ 에 해당하였고, 대조군에서는 $17.5 \%$ 로 odds ratio 1.926 (95\% 신뢰구간, 1.094-3.389)로 통계적으로 유의한 것으로 나타났다. 흥미롭게도, rs35744813의 경우, 환 자군과 대조군간의 유전자형 및 대립인자의 빈도에 대한 결과 가 rs307355과 동일하게 나타났다(Fig. 1). 두 다형성에 대한 일배체형을 분석한 결과를 보면 C-C 및 T-T의 두 종류만이 검출되었으며 환자군과 대조군간의 일배체형 빈도간에도 통 계적으로 유의한 차이를 보였다 $(p<0.022)$ (Table 2). Fushan 등[3]의 보고에 따르면, rs307355와 rs35744813에 대한 대립유 전자 빈도 분석 대립인자T의 빈도는 아프리카 $37 \%$, 아시안 $22 \%$, 그리고 백인집단 $8 \%$ 로 가장 낮았다. 본 연구에서 조사된 대조군의 경우에 대립인자 T의 빈도는 $29 \%$ 로 기존의 연구에 서 보고된 전세계 집단의 평균빈도인 $14 \%$ 보다 높은 것으로 나타났다. 또한, 한국인 집단에서는 단지 두 종류의 일배체형 이 존재하였는데, 이 결과는 두 다형성이 강한 연관불평형을 이루어 아프리카집단을 제외한 아시아와 유럽집단에서는 두 종류의 일배체형(C-C 및 T-T)이 99\% 이상으로 나타낸 기존의 연구결과와 매우 유사하다고 할 수 있다. 또한, 두 다형성의 유전자형인 $\mathrm{C} / \mathrm{T}$ 와 $\mathrm{T} / \mathrm{T}$ 를 지닌 개체가 $\mathrm{C} / \mathrm{C}$ 를 가진 개체보다 단맛의 민감도에 대해 $25 \%$ 와 $50 \%$ 낮은 것으로 보고되고 있는 데, 본 연구에서 조사된 환자군의 $\mathrm{C} / \mathrm{T}$ 및 $\mathrm{T} / \mathrm{T}$ 유전자형의 빈도가 대조군보다 높다는 사실은 미각장애와 TAS1R3 유전
자 간의 연관성이 있을 가능성을 제시해 준다고 할 수 있다.

GNAT3 유전자의 유전자형은 rs7792845의 경우 유전자형 빈도는 환자군과 대조군간에 유의적인 차이를 보였으나 $(p<0.048)$, 대립유전자빈도는 통계적인 유의성을 나타내지 않았으며 rs 1524600 의 경우도 두 군간의 유전자형 및 대립 유전자 빈도의 차이는 관찰되지 않았다(Table 3). 두 다형성 에 대한 일배체형 구축한 결과, C-T, C-C, T-C의 세 종류 일 배체형이 $98 \%$ 이상으로 산출되어 나머지 한 종류는 분석에 서 제외시켰다. 일배체형 분석 결과, 환자군 및 대조군에서 모두 $\mathrm{C}-\mathrm{C}$ 형이 환자군 $60.1 \%$, 정상군 $55 \%$ 의 빈도로 가장 높게 나타났다(Table 4). 이들 일배체형의 빈도는 두 군간에 통계적으로 유의한 차이가 없었다. 선행 연구에 따르면, GNAT3 유전자를 암호화하는 부위로부터 $10 \mathrm{~kb}$ 떨어진 부 위에 위치한 rs7792845이 개체 간의 단맛 민감도와 연관되 어 있다고 보고하였는데, 본 연구에서도 환자군과 대조군 간의 빈도간에 차이가 관찰되었다.

인간 게놈에 대한 염기서열이 밝혀지고 일배체형에 대한 분석이 활발히 진행됨에 따라 개인의 게놈정보를 바탕으로 한 맞춤의학(personalized medicine)과 영양유전체학 (nutrigenetics)에 대한 연구가 활기를 띄고 있는데, 최근 들어, 미각분야에서도 개인간 염기서열의 차이가 맛을 인지하는데 중요한 역할을 한다는 사실이 쓴맛과 감칠맛에서도 보고된 바 있다[6,9]. 본 연구에서는 단맛의 민감도 차이에 영향을 미 치는 것으로 보고된 TASIR3 및 GNAT3 유전자의 다형성에 대한 한국인 집단에서의 유전자형 빈도를 조사하였으며 미각 장애환자군과의 비교분석을 통해 TAS1R3 유전자의 다형성이 연관성이 있을 가능성이 있음을 제시하였다. 이러한 연구결과 는 집단유전학적 연구 및 미각장애를 진단하기 위한 검사 시

Table 1. Results of association analysis for SNPs in the TAS1R3 gene between controls and cases

\begin{tabular}{|c|c|c|c|c|c|c|c|c|}
\hline \multirow{2}{*}{ SNPs } & \multicolumn{3}{|c|}{ Genotype } & & \multicolumn{4}{|c|}{ Allele } \\
\hline & Controls (\%) & Cases (\%) & $p\left(x^{2}\right)$ & & Controls (\%) & Cases (\%) & $p\left(x^{2}\right)$ & ORs $(95 \% \mathrm{CI})$ \\
\hline \multicolumn{9}{|l|}{ rs307355 } \\
\hline $\mathrm{CC}$ & $67(67.0)$ & $28(56.0)$ & & $\mathrm{C}$ & $165(82.5)$ & $71(71.0)$ & \multirow{3}{*}{0.022} & \multirow{3}{*}{$1.926(1.094-3.389)$} \\
\hline $\mathrm{CT}$ & $31(31.0)$ & $15(30.0)$ & 0.013 & $\mathrm{~T}$ & $35(17.5)$ & $29(29.0)$ & & \\
\hline TT & $2(2.0)$ & $7(14.0)$ & & & & & & \\
\hline \multicolumn{9}{|l|}{ rs35744813 } \\
\hline $\mathrm{CC}$ & $67(67.0)$ & $28(56.0)$ & & $\mathrm{C}$ & $165(82.5)$ & $71(71.0)$ & \multirow{3}{*}{0.022} & \multirow{3}{*}{$1.926(1.094-3.389)$} \\
\hline $\mathrm{CT}$ & $31(31.0)$ & $15(30.0)$ & 0.013 & $\mathrm{~T}$ & $35(17.5)$ & $29(29.0)$ & & \\
\hline TT & $2(2.0)$ & $7(14.0)$ & & & & & & \\
\hline
\end{tabular}

Significant results $(p$ value $<0.05)$ are shown in bold.

Table 2. Haplotype analysis for predicted haplotypes in the TASIR3 gene

\begin{tabular}{ccccc}
\hline Haplotypes & Controls (\%) & Cases (\%) & $p\left(x^{2}\right)$ & ORs (95\% CI) \\
\hline CC & $165(82.5)$ & $71(71.0)$ & \multirow{2}{*}{0.022} & $0.52(0.30-0.91)$ \\
TT & $35(17.5)$ & $29(29.0)$ & & $1.93(1.09-3.39)$ \\
\hline
\end{tabular}

Significant results $(p$ value $<0.05)$ are shown in bold. 
Table 3. Results of association analysis for SNPs in the GNAT3 gene between controls and cases

\begin{tabular}{|c|c|c|c|c|c|c|c|c|}
\hline \multirow{2}{*}{ SNPS } & \multicolumn{3}{|c|}{ Genotype } & & \multicolumn{4}{|c|}{ Allele } \\
\hline & Controls (\%) & Cases $(\%)$ & $p\left(x^{2}\right)$ & & Controls $(\%)$ & Cases (\%) & $p\left(x^{2}\right)$ & ORs $(95 \%$ CI $)$ \\
\hline \multicolumn{9}{|c|}{ rs7792845 } \\
\hline $\mathrm{CC}$ & $46(46.0)$ & $21(42.0)$ & \multirow{3}{*}{0.048} & $\mathrm{C}$ & \multirow{3}{*}{$\begin{array}{c}138(69.0) \\
62(31.0)\end{array}$} & \multirow{3}{*}{$\begin{array}{ll}60 & (60.0) \\
40 & (40.0)\end{array}$} & \multirow{3}{*}{0.121} & \multirow{3}{*}{$1.484(0.900-2.446)$} \\
\hline $\mathrm{CT}$ & $46(46.0)$ & $18(36.0)$ & & $\mathrm{T}$ & & & & \\
\hline $\mathrm{TT}$ & $8(8.0)$ & $11(22.0)$ & & & & & & \\
\hline \multicolumn{9}{|c|}{ rs1524600 } \\
\hline $\mathrm{CC}$ & $81(81.0)$ & $45(90.0)$ & & $\mathrm{C}$ & $180(90.0)$ & $95(95.0)$ & \multirow{3}{*}{0.140} & \multirow{3}{*}{$2.111(0.768-5.802)$} \\
\hline $\mathrm{CT}$ & $18(18.0)$ & $5(10.0)$ & 0.331 & $\mathrm{~T}$ & $20(10.0)$ & $5(5.0)$ & & \\
\hline TT & $1(1.0)$ & $0(0.0)$ & & & & & & \\
\hline
\end{tabular}

Significant results $(p$ value $<0.05)$ are shown in bold.
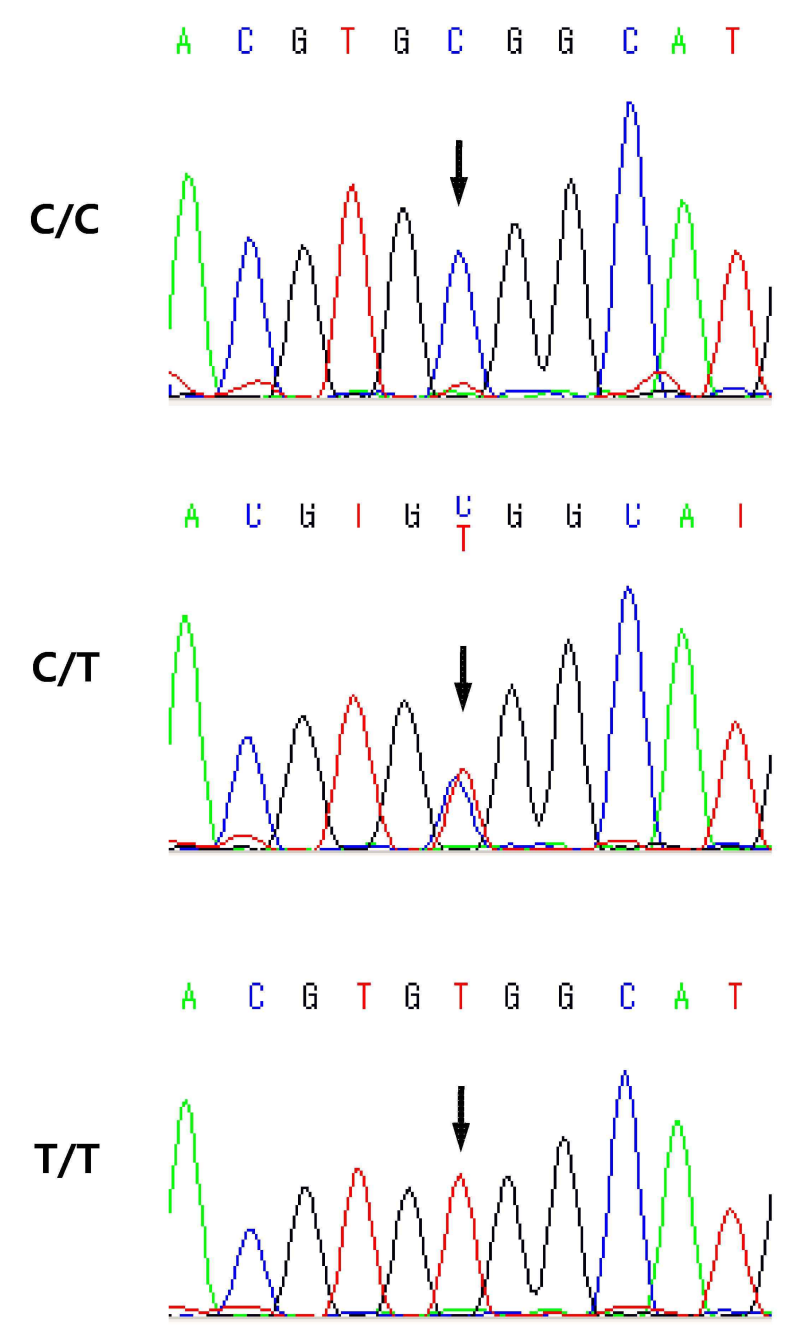

Fig. 1. Sequence chromatograms showing the rs354744813 polymorphism in the TAS1R3 gene.

지표로 활용하기 위한 연구에 중요한 기초자료로 이용되리라 판단되며 향후 대상 환자 수와 대조군을 더욱 늘리고 다양한 유전자 다형성을 후보로 하여 추가적인 연구가 필요하리라 본다.
Table 4. Haplotype analysis for predicted haplotypes in the GNAT3 gene

\begin{tabular}{cccccc}
\hline Haplotypes $^{\text {a }}$ & Controls $(\%)$ & Cases $(\%)$ & $p\left(\chi^{2}\right)$ & ORs $(95 \%$ CI $)$ \\
\hline CC & $119(60.1)$ & $55(55.0)$ & 0.399 & $1.23(0.76-2.00)$ \\
CT & $19(9.6)$ & $5(5.0)$ & 0.169 & $2.02(0.73-5.57)$ \\
TC & $60(30.3)$ & $40(40.0)$ & 0.094 & $0.65(0.39-1.08)$ \\
\hline
\end{tabular}

${ }^{a}$ Haplotypes observed with $<0.02$ in both controls and cases have been dropped.

\section{감사의 글}

이 논문은 2008년도 정부재원(교육인적자원부 학술연구조 성사업비)으로 한국학술진흥재단의 지원을 받아 연구되었음 (KRF-2008-E00050).

\section{References}

1. Chaudhari, N. and S. D. Roper. 2010. The cell biology of taste. J. Cell Biol. 190, 285-296.

2. Fushan, A. A., C. T. Simons, J. P. Slack, and D. Drayna. 2010. Association between common variation in genes encoding sweet taste signaling components and human $\mathrm{su}^{-}$ crose perception. Chem. Senses 35, 579-592.

3. Fushan, A. A., C. T. Simons, J. P. Slack, A. Manichaikul, and D. Drayna. 2009. Allelic polymorphism within the TAS1R3 promoter is associated with human taste sensitivity to sucrose. Curr. Biol. 19, 1288-1293.

4. Gilbertson, T. A., S. Damak, and R. F. Margolskee. 2000. The molecular physiology of taste transduction. Curr. Opin. Neurobiol. 10, 519-527.

5. Jiang, P., Q. Ji, Z. Liu, L. A. Snyder, L. M. Benard, R. F. Margolskee, and M. Max. 2004. The cysteine-rich region of T1R3 determines responses to intensely sweet proteins. $J$. Biol. Chem. 279, 45068-45075.

6. Kim, U. K., E. Jorgenson, H. Coon, M. Leppert, N. Risch, and D. Drayna. 2003. Positional cloning of the human quantitative trait locus underlying taste sensitivity to phenylthiocarbamide. Science 299, 1221-1225.

7. Lim, G. H., S. H. Shin, and M. K. Ye. 2009. Clinical 
Investigations in Patients with Taste Disorder. Korean J. Otorhinolaryngol-Head Neck Surg. 52, 413-418.

8. Nelson, G., M. A. Hoon, J. Chandrashekar, Y. Zhang, N. J. Ryba, and C. S. Zuker. 2001. Mammalian sweet taste receptors. Cell 106, 381-390.

9. Shigemura, N., S. Shirosaki, K. Sanematsu, R. Yoshida, and Y. Ninomiya. 2009. Genetic and molecular basis of individual differences in human umami taste perception. PLoS One 4, e6717.
10. Smith, D. V. and R. F. Margolskee. 2001. Making sense of taste. Sci. Am. 284, 32-39.

11. Xu, H., L. Staszewski, H. Tang, E. Adler, M. Zoller, and X. Li. 2004. Different functional roles of T1R subunits in the heteromeric taste receptors. Proc. Natl. Acad. Sci. USA 101, 14258-14263.

12. Zhao, G. Q., Y. Zhang, M. A. Hoon, J. Chandrashekar, I. Erlenbach, N. J. Ryba, and C. S. Zuker. 2003. The receptors for mammalian sweet and umami taste. Cell 115, 255-266.

\section{초록 : 미각장애와 TAS1R3 및 GNAT3 유전자의 다형성과의 연관성}

배재웅 ${ }^{1 \dagger} \cdot$ 김언경 ${ }^{1 \dagger} \cdot$ 권태준 $^{1} \cdot$ 최수진 ${ }^{1} \cdot$ 예미경 ${ }^{2}{ }^{*}$

( ${ }^{1}$ 경북대학교 생물학과, ${ }^{2}$ 대구가톨릭대학교 의과대학 이비인후과교실 $)$

단맛은 우리 몸에 열량을 공급하는 역할을 담당하는 중요함 감각으로 인지도가 개인마다 조금씩 다르다고 알려져 있으나, 이에 대한 분자수준의 연구는 아직 부족한 실정이다. 본 연구에서는 미각 장애에 미치는 유전적 요인에 대해 알아보고자 50 명의 미각 환자 및 100 명의 정상인을 대상으로 단맛 민감도 차이와 연관이 있는 TAS1R3 및 GNAT3 유전 자의 다형성 간의 관련성을 알아보았다. TAS1R3 유전자 rs307355 및 rs35744813의 유전자형과 대립유전자의 빈도는 미각 장애 환자군과 대조군 간에 통계적으로 유의한 차이가 있었으며, 두 다형성에 대한 일배체형을 분석한 결과, C-C 및 T-T의 두 종류만이 검출되었으며 환자군과 대조군 간의 일배체형 빈도 간에도 통계적으로 유의한 차이를 보였다. GNAT3 유전자에서는 rs7792845의 유전자형 빈도가 환자군과 대조군간에 유의적인 차이를 나타냈었으나, 대립유전자 빈도에서는 차이가 없었다. 이러한 연구결과는 단맛의 민감도 차이에 영향을 미치는 것으로 보고된 TASIR3 및 GNAT3 유전자의 다형성에 대한 한국인 집단에서의 유전자형 빈도를 조사함으로써 집단유전학적 연구를 위한 기초자료를 제 공하고 미각장애환자군과의 비교분석을 통해 TAS1R3 및 GNAT3 유전자의 다형성이 연관성이 있을 가능성이 있음을 제시해 줌으로써 향후 미각장애를 진단하기 위한 검사시 지표로 활용될 수 있으리라 생각된다. 위에 제시한 연구결과는 향후 추가적인 샘플링을 통해 보다 많은 환자군과 대조군에 대한 추가적인 연구가 수행되어야 할 것이다. 